\title{
How Peers Influence Children's Smoking Behavior
}

\author{
Andi Tenri Awaru \\ Department of Health Promotion and \\ Behavioral Science \\ Hasanuddin University \\ Indonesia
}

\author{
Mappeaty Nyorong \\ Department of Health Promotion and \\ Behavioral Science \\ Hasanuddin University \\ Indonesia
}

\author{
Muhammad Rachmat \\ Department of Health Promotion and \\ Behavioral Science \\ Hasanuddin University \\ Indonesia \\ rachmat.muh@gmail.com
}

\begin{abstract}
Smoking is a risky behavior that is increasingly popular among young people. Smoking behavior is influenced by many factors, one of which is the role of peers. This study aims to identify the role of peers in primary school children smoking behavior. This research uses qualitative method with phenomenology design. Data collection is done by observation and in-depth interview and then analyzed by content analysis. The results show influence if peers in children smoking behavior comes in many form, which are affordability of information, social support, and possible situations. Peers do not play a role in influencing the child's personal autonomy which shows that the majority of children make their own decisions to smoke. It is concluded that peers influence smoking behavior in primary school children.
\end{abstract}

\section{Keywords—Smoking behavior; primary school aged children}

\section{INTRODUCTION}

Cigarettes are the main cause of the many preventable death cases. Indonesia ranks fourth as country with the largest cigarette consumption after China, Russia, and America [1]. Riskesdas (Indonesia Basic Health Research) shows an increasing trend of smokers' proportion in Indonesia from year to year [2]. In addition to this increase, the shifting age of beginner smokers to the seven years old child is a concern.

A study of 178 elementary school students in Bandar Lampung, Indonesia shows that peers have significant role in influencing smoking behavior. According to this study, children who have good friends are less likely to smoke [3]. Similar result also found in South Jakarta, Indonesia, where studies on Junior High School students shows that $66 \%$ of children smoker are influence by their peers. furthermore, children who have a smoker friend are 14.412 more likely to become a smoker [4]

Smoking behavior in adolescents has been extensively investigated in scientific articles. However, the age of smoke initiation has shifted to elementary school age. Hence, future study of smoking behavior in primary school-aged children is required. So far, only few studies have analyzed children smoking behavior using an in-depth, qualitative approach. Therefore, this presents study times to identify smoking behavior of primary school children especially from the peer role aspect.

\section{LITERATURE REVIEW}

Behavior is an individual's response or reaction to stimuli from environment. There are various theories of behavior, but in general, factors affecting behavior are divided in two factors, namely internal factors and external factors. Green Proposes that behavior is influenced by three factors: predisposing factor, enabling factor, and reinforcing factor. Predisposing factor refers to behavioral trigger which allow a person, group, or society to smoke. It includes knowledge, attitude, tradition, and belief regarding cigarettes and smoking behavior, the dangerous effect of smoking cigarettes, and harmful substances in cigarettes. Enabling factor refers to facilitating factor which allow smoking behavior, such as cigarettes availability, and ease of getting cigarettes. Reinforcing factors refers to parents, siblings, idol, health workers, teachers, peer group, and exposure of cigarette advertisement [5]. As a person grow and developed, his behavior can change as a result of various interaction with environment of which manifested in the form of knowledge, attitude and action [6].

Smoking behavior alone is a risky behavior that endangers good health for active and even for passive smokers. There are up to 4000 hazardous materials contained in cigarettes, including nicotine, tar and carbon monoxide. Davison and Neale [7] stated that being a cigarette addict occurred in several stages. The first stage begins with a positive attitude toward smoking. The second stage occurs when individuals start smoking experimentally. The third stage arise when a person starts to smoke regularly, until eventually become heavy smokers who are already in the phase of addiction.

Lindawati [4] suggests that there are seven variables that influence smoking behavior of junior high school students: gender; perception; parental behavior; mother education; teacher influence; Peers, and children allowances. This research was analyzed by quantitative approach. This approach, however, have failed to provide opportunity to 
explore respond from participants. Behavior, on the other hand is formed through complicated and complex processes and thus category alone will not explain the causal effect. Narrative and descriptive descriptions are required.

\section{METHOD}

\section{A. Participants}

There were 13 participants recruited by purposive random sampling after consideration that they know and can be trusted to provide a trustworthy and detail information. Criteria for selecting the participants were as follows: Children aged 6-12 years; elementary school students; smoking, not suffering from any disease or disorder

\section{B. Procedure}

The research is a qualitative research with phenomenology design. The data was collected by observation and in-depth interview. Observations were made to obtain preliminary data regarding the location of the study and to validate the results of the interview. Prior to In-depth interview, each participant received an explanation of the study and then were asked to fill the informed consent should they agree to participate in this study. After that, in-depth interview was conducted privately and secretly. Each investigator was equipped with observation sheets, interview guides and documentation tools such as cameras and tape recorders.

The data collected is processed using content analysis and presented in narrative form. The validity of the data was obtained using technique triangulation and source triangulation. Triangulation technique is done by using more than one method of data collection, namely observation and depth interview. Triangulation of sources is done by using more than one data source. In addition to elementary school children, other sources of information are teachers, cigarette sellers and internet cafe employees.

\section{RESULT}

Smoking behavior is a function of person and its environment. Besides caused by internal factors, smoking behavior is also caused external factors, which is the environment. Referring to the concept of behavior transmission, behavior can be transmitted vertically and horizontally. Vertical transmission is performed by parents while horizontal transmission can be performed by peers [8]. The role of peers in child smoking behavior can be reviewed from five factors of behavior determinants: child smoking intentions; affordability; social support; personal autonomy; and supportive situations [6].

Children's smoking intentions can be understood from their smoking history during their initial smoking behaviour and their motivation to continue smoking. Based on the results of data collection, initial smoking behavior was influenced by children's peers in various forms. Some of them were asked to accompany a friend to buy cigarettes, some other were caused by seeing their friends buy a cigarette, while some other were scared because their friend are threatening them.

"My friend were asked me, lets buy a cigarette... by a
friend. by D. Finally, I follow him and started to get
addicted"

(RH, 11-year-old)

"I do what my friend do at internet cafe" (F, 12-year-old)

"I am afraid of $A$."

(AA, 11-year-old)

Those participants who still smoking, are mostly motivated by peer pressure. Some imitate friends smoking behavior, some other are forced, and some other are motivated by the physiological comfort effect provide by smoking.

"I smoke because most of my friends still smoking." (AY, 12-year-old)

"I was forced by a friend, sometime he beats me." (MRR, 11-year-old)

"I enjoy when I smoke., especially when the smoke coming out of my nose. I feel so relaxed."

(RH, 11-year-old)

Information about cigarettes influence knowledge and formation of perception. Knowledge and perception are predisposing factors that influence behavior. Based on the results of this study, information obtained by informants from their friends are mostly pro smoking behavior. For example, cigarettes are good and will not cause dizziness. In contrast, only few of them get information about the dangerous of cigarette.

"Sucking on cigarettes is tasty. sometimes its sweet,
sometimes its bitter." (FP, 12-year-old)

"I feel dizzy if I don't smoke a cigarette." (AS, 9-year-old)

"it is uncomfortable, it makes me dizzy"

(MRR, 11-year-old)

Social support is a behavior determinant that comes from outside of the person. Such support is formed as a result of a person socialization with people around him/her. Smoking behavior is a risky behavior that can damage health. Nevertheless, the informant still gets social support regarding his smoking behavior from those around him, in this case from peers. 
House distinguishes social support into four forms: instrumental support; emotional support; appraisal support; and information support [9]. Data obtained in this study regarding social support can be divided into House's categorization:

TABLE I. SOCIAL SUPPORT BASED ON HAUSE CATEGORIZATION

\begin{tabular}{|c|c|c|}
\hline $\begin{array}{l}\text { Social } \\
\text { Support }\end{array}$ & Findings & Quotation \\
\hline \multirow{2}{*}{$\begin{array}{l}\text { Instrumental } \\
\text { Support }\end{array}$} & \multirow{2}{*}{$\begin{array}{l}\text { Give Cigarettes } \\
\text { of Give money } \\
\text { to buy cigarette }\end{array}$} & $\begin{array}{l}\text { "AP often buy me a cigarette, we } \\
\text { both like to smoke." } \\
\text { (MDF, 12-year-old }\end{array}$ \\
\hline & & $\begin{array}{l}\text { “.. If I accompany him I buy } \\
\text { him, he will buy me a cigarette.” } \\
\text { (FP, 12-year-old) }\end{array}$ \\
\hline $\begin{array}{l}\text { Emotional } \\
\text { Support }\end{array}$ & $\begin{array}{l}\text { Apathy and } \\
\text { pessimistic attitude }\end{array}$ & $\begin{array}{l}\text { "Sometimes I have to buy my } \\
\text { friend cigarettes. they will mad at } \\
\text { me if I don't do that." } \\
\text { (RH, 11-yearl-old) }\end{array}$ \\
\hline $\begin{array}{l}\text { Appraisal } \\
\text { Support }\end{array}$ & Smoking invitation & $\begin{array}{l}\text { " } R \text { always ask me to join him to } \\
\text { smoke" } \\
\text { (AA, 11-year-old) } \\
\text { " } S \text {, my friends always tell me to } \\
\text { smoke." } \\
\text { (MA, 11-year-old) }\end{array}$ \\
\hline $\begin{array}{l}\text { Informative } \\
\text { Support }\end{array}$ & $\begin{array}{l}\text { Information about } \\
\text { cigarette }\end{array}$ & $\begin{array}{l}\text { "...S teaches me to smoke." } \\
\text { (FP, 12-year-old) }\end{array}$ \\
\hline
\end{tabular}

Source: Primary Data, 2016

This present study also intent to investigate peer role to participant's authority in deciding things associated with smoking behavior. Based on the data, the majority of informants engage in smoking behavior because of their own decision. Informants use their personal autonomy to decide whether to smoke or not

"That is what I want"

(DK, 12-yearl-old)

"Because that is what I want"

(AD, 12-year-old)

Only four participants are influenced by their peer in utilizing their autonomy making decision regarding their smoking behavior. After further exploration, it is discovered that they also smoke because of their peer influence.

"Because of my friend."

(MA, 11-year-old) "because my friend forces me to."

(MRR, 11-year-old)

Furthermore, peers influence on smoking behavior is more evident as participants reveal that most of the time they accompanied by their friends when smoking a cigarette. friends in this context are their school friends, playmates, and both. When asked to name the peers who accompanied them to smoke, the informant mentioned at least one to five names

"with my friend at internet cafe."

(TP, 12-year-old)

"with my neighborhood friends, his name is AR."

(MRR, 11-year-old)

"with my friends. sometimes with $B B, A f, R f, S d, A l$, at internet cafe while eating and playing games."

(FP, 12-year-old)

The majority of the participants are smoking cigarettes while outside their house, for example when gather with friends, or while visiting internet cafe. Moreover, participants only smoke cigarettes in a place where it is possible to smoke, for example at a place near their house or at internet cafe, or places where they can rent and play with PlayStation.

\section{DISCUSSION}

Children are a vulnerable age group who are potentially become a long-term smoker. Smokers who smoke in the long run are at risk of death three times higher than those who are not smokers [4]. Smoking at an early age also provides greater risk for other deviant behaviors. Smoking can be a beginning before starting to smoke marijuana and various types of drugs [10].

The development of the children's personality is not only influenced by parents and family, but also by the school environment as well as social friends outside school [3]. As children grow and developed, they start to withdraw from his interaction with their parents to develop new values. The formation of new values is done by the identification, imitation of certain figures, and by developing their own.

Prior study on healthy behaviors and the peer role suggests that peers can lead to a decline in healthy behaviors or vice versa, may improve healthy behavior. In a group of friend, if one most influential person in the group changes his behavior, then it is very likely other members will follow to change his behavior. This social effect is known as the social multiplier [11]. 
According to Theory of Planned Behavior, intention is consciously formed and it reflects how strong a person willingness to perform certain behavior. Intention is assumed to be the motivation that influence behavior. The result of this study shows that peers have significant role in influencing smoking behavior. Participants' smoking history and motivation to smoke cigarettes are affected by their peers. thus, peers play a role as initiation agents to smoke and also motivate participants to smoke

Leventhal and Clearly state that smoking behavior develop through four stages. The first stage is a preparatory stage in which the individual has a positive picture of a cigarette which then encourages his interest in trying to smoke a cigarette [12]. in this case, positive description about cigarettes is obtained through peers. There is availability of cigarette information from peers. Many participants get information that is pro (positive) to cigarettes. This positive perception can lead participants to the next stage of trial smoking and then to the final stage when they are addicted to smoke.

According to the Protection Motivation Theory, information sources are divided into two types. The first type is the environment, e.g. verbal persuasion and observation learning. The second is intra personal in the form of learning from previous experience. The result of this study shows that peers have an influence in providing information about cigarettes verbally and also become role models for participants. Smoking peers become the object of observation and learning about smoking behavior.

Social support refers support in the form of perceived pleasure, awareness of care, and assistance to other people or groups [9]. Support receive from peers are instrumental support, emotional support, appreciation support and informative support.

Instrumental support is provided in the form material supply. Peers provide cigarette and money to buy cigarette. According Lawrence Green's Theory, this support is classified as an enabling factor. Emotional support is a form of support that involves feelings and it is reflected in the form of attitude or action. The result of this study shows that the majority of peers showed apathy and permissive attitude toward smoking behavior. This attitude form confirmation of smoking behavior. Based on observations, smoking behavior has become commonplace in school neighborhoods. Appreciation support provides positive appreciation, encouragement and approval on individual opinions. Peers provide this support in the form of an invitation to smoke. According to Lawrence Green's theory, this support is classified as a reinforcing factor. Information support involves providing information, suggestions or feedback about individual situations and conditions. In this study, information support is provided in the form of information availability regarding smoking behavior. Participants receive various information about smoking from their peers. In Lawrence Green's theory, this support is classified as a predisposing factor [5].

Personal autonomy or personal freedom should be fully the property of the individual. In making decisions about smoking behavior, most participants (9 out of 13) use their full personal autonomy. Only four informants were affected by their peers which means that peers become reference groups for them so they are making their decisions guided by their peers. There are also participants who their history, motivation and decision are influenced by peer pressure. Peer pressure occurs when individual experiences persuasion that makes $\mathrm{him} / \mathrm{her}$ would do the same thing done by peers. Some participants have peers who use coercive attitude, they are not even reluctant to cursing and punching participants to smoke.

In making friends with peers, the need to be the part of a social group is the major goal [8]. Individuals tend to follow everything that is done by peers so they seem to have the same values and behavior. There is a fear of losing their social groups if they do not follow what is trending in the group. Unfortunately, most children today have misperceptions about the acceptance of social groups. They consider smoking behavior as a social norm to be follow if they want to be accepted. This situation is defined as a false consensus effect [11].

Conditions and situations can be defined available facilities and existing capabilities. Peers have a great influence as a person who know participants' smoking behavior and participants friends whom they smoke cigarettes with. Moreover, gathering with friends are considered conducive situation to smoke.

Peers have a strong influence in child smoking behavior. Children are willing to spend more time with their peers rather than their parents [11]. Field observations show that participant spent about five hours with school friends and about four to six hours with their playmate. Children aged 1012-year-old are closer to their peers and wants to feel freedom [3]. The majority of participants are also children with low supervision from their parents. There is low intervention from parents regarding what children do with their friends.

The role of peers in children smoking behavior occurs through the mechanism of peer socialization. A child with a smoking friend are more likely to be influenced to smoke. There is also a tendency that a smoking children will also choose a smoking friend [13]. In addition, making friends with smoking friends will elevate the risk to increasing smoking intensity. Smoking friends can be a contributing factor as well as well as a behavioral amplifier factor. The need for acceptance often leads children to do whatever it takes to be accepted by the group and free from the labelling such as 'coward' or 'sissy'. Children may experience internal pressure to smoke if others around them smoke [14]. 
Peers also act as intermediary agents of smoking socialization [15]. Smoking peers allow individual smoking behavior because it creates facilitating condition to smoke. peers invited children to smoke, providing them with cigarettes or money to buy cigarettes and also have friends of whom they share the same behavior (i.e. smoking cigarettes). If a child smoke, it is likely that his peers are also a smoker. Vice versa, if their peers smoke, it is likely that the children is also a smoker.

The limitation of this study is that population of this study is restricted to middle-low economic population. as a consequence, it fails to provide explanation regarding role of peers in smoking behavior of participants from middle to upper economic.

This study provide evidence that smoking behavior has reached primary school-aged children. Parents should give more attention and supervision in order to prevent children from bad influence of their peers. Further research is required to discuss this further, especially, related to how parenting and the influence of parents' smoking behavior on primary school age children.

\section{CONCLUSION}

Peers have a significant role in influencing smoking behavior of primary school children. Peers influence children smoking behavior by influencing children's smoking intentions, affordability, social support and possible situations. However, Peers do not influence the child's personal autonomy. Most children use their full personal autonomy in deciding everything related to their smoking behavior. We suggest that in order to prevent the growing number of young smokers, a specific approach is needed. In a social group, generally there is one person who becomes the source of influence. This influential person needs to be given special intervention and thus peer can be used to improve the degree of healthy life behavior, not to lower it.

\section{REFERENCES}

[1] M.P.Eriksen, J. Mackay, N. Schluger, et al. "The Tobacco Atlas." $5^{\text {th }}$ ed., Atlanta: American Cancer Society, 2015

[2] Kementerian Kesehatan Republik Indonesia, Riset Kesehatan Dasar, Riskesdas 2013

Available:

http://www.depkes.go.id/resources/download/general/Hasil\%20Ris kesdas\%202013.pdf [6Dec 2017]

[3] E.D. Firdaus, T.A. Larasati, R. Zuraida, A. Sukohar "Hubungan Pergaulan Teman Sebaya terhadap Tindakan Merokok Siswa Sekolah Dasar Negeri di Kecamatan Panjang Kota Bandar Lampung. "Jurnal Kedokteran Universitas Lampung. Vol. 3 pp. 56-61.

[4] Lindawati, B. Miradwiyana, Sumiati. "Faktor-Faktor yang Mempengaruhi Perilaku Merokok Siswa-Siswi SMP di Daerah Jakarta Selatan,” Jurnal Health Quality, vol. 2, pp. 189-200, 2012
[5] K. Glanz, B.K. Rimer, K. Viswanath. Health behavior and health education: theory, research, and practice. Sanfransisco, CA: John Wiley \& Sons 2008.

[6] S. Notoatmodjo. Promosi Kesehatan Teori dan Aplikasi. Jakarta: Rineka Cipta, 2013.

[7] G.C. Davison, J.M. Neale, Abnormal Psychology. New York: John Willey and Sons, 2001.

[8] D. Komasari, A.F.Helmi. "Faktor-Faktor Penyebab Perilaku Merokok pada Remaja," Jurnal Psikologi, vol. 1. 2000, pp.37-47.

[9] B. Smet, Psikologi Kesehatan. Jakarta: Grasindo, 1994.

[10] A. Hublet, P.Bendtsen, M.E.de Looze, A. Fotiou, P. Donnely, R. Vilhjalmsson, T. Baska, I.P. Franelic, S. Nic Gabhainn, t.f. TER Bogt "Trends in the Co-occurance of Tobacco and Cannabis Use in 15-Year-Olds from 2002 to 2010 in 28 Countries of Europe and North America," The European Journal of Public Health., vol. 2, pp. 73-75, Apr 2015

[11] L. M. Yarnell, H. S. Brown, K.E. Pasch, C.L. Perry, K.A. Komro. "Classroom Norms and Individual Smoking Behavior in Middle School," Am Journal Health Behavior, vol. 36, pp. 12-19, Januari 2012.

[12] T. Mulyani. Dinamika Perilaku Merokok pada Remaja. Solo: Universitas Muhammadiyah Surakarta, 2015.

[13] K. Astuti. "Gambaran Perilaku Merokok pada Remaja di Kabupaten Bantul," Jurnal Insight, vol. 10, pp. 77-87, Februari 2012.

[14] M. Rachmat, M.R. Thaha, M. Syafar, "Perilaku Merokok Remaja Sekolah Menengah Pertama," Jurnal Kesehatan Masyarakat Nasional, vol. 7. 2013, pp. 502-508.

[15] A. T. Awaru. Perilaku Merokok pada Anak Sekolah Dasar di Kota Makassar. Makassar: Universitas Hasanuddin, 2016. 